\title{
Bilateral cranial hemophilic pseudotumors
}

Figure 1 Cranial CT and MRI

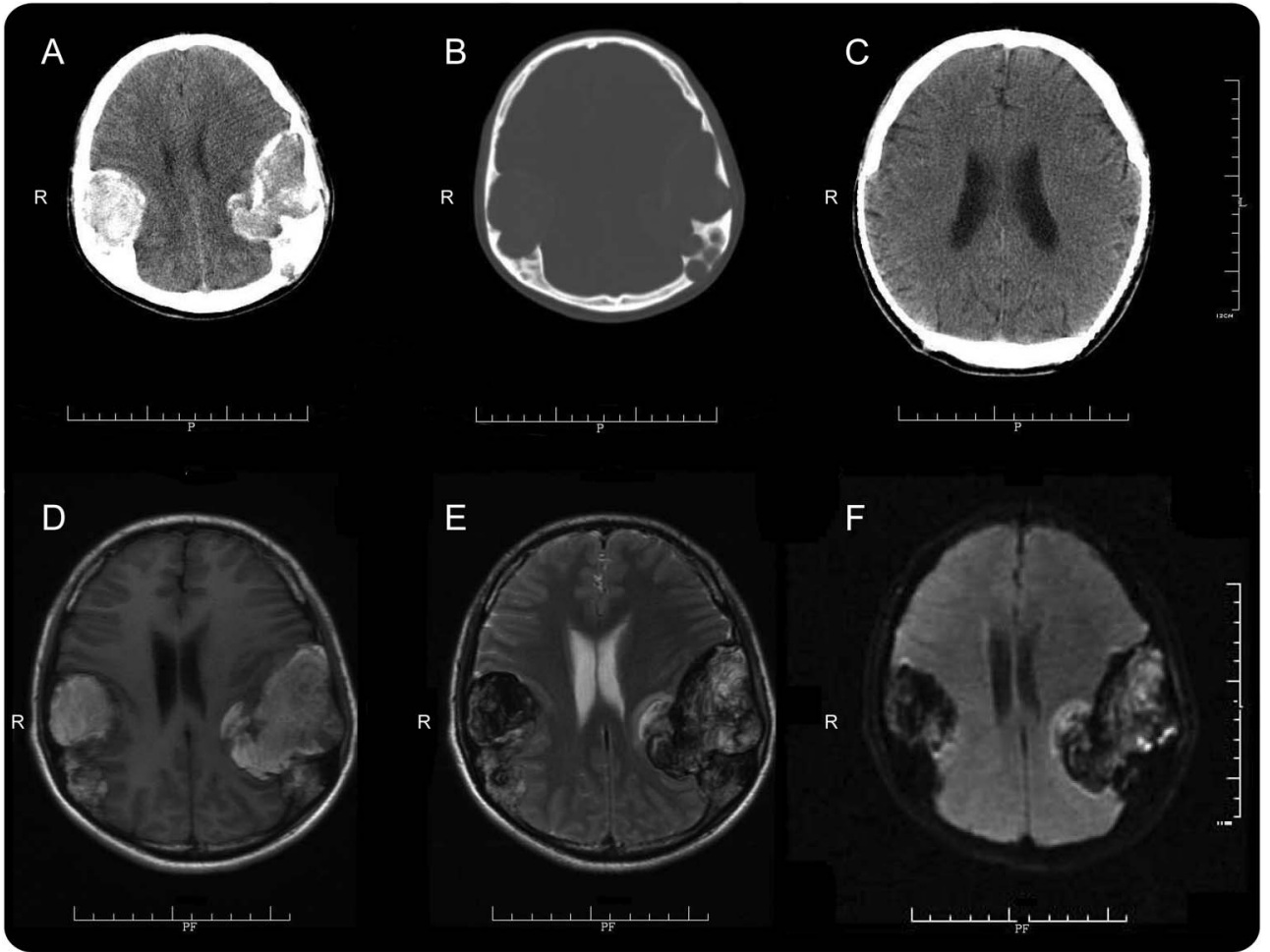

Axial CT scan (A) demonstrates heterogeneous high-density lesions with irregular bone erosion when set to bone window (B). A 3-year follow-up CT scan (C) shows no sign of recurrence. T1-weighted (D), T2-weighted (E), and diffusion-weighted MRI (F) reveal heterogeneous extra-axial lesions on images consistent with chronic hemorrhage of varying ages.

\section{Figure 2 Intraoperative photographs}

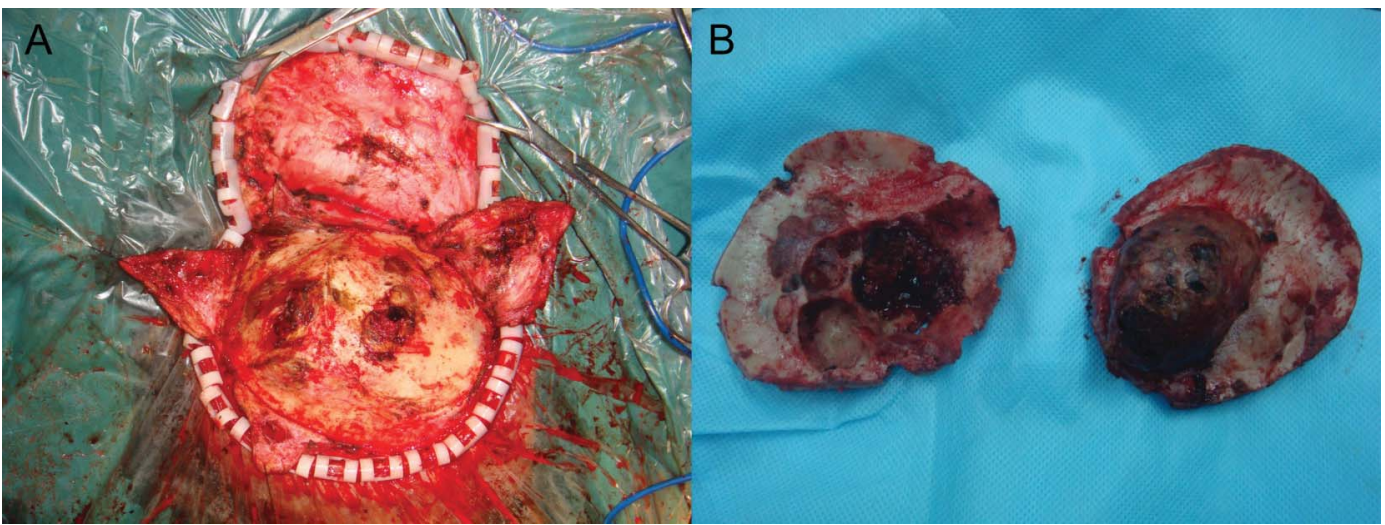

At operation, hemophilic pseudotumors were observed with subgaleal and epidural extension (A). Resected surgical specimens (B) show multicystic masses containing clotted blood. 
A 39-year-old man with mild hemophilia A presented with a 6-month history of repeated headache with mild difficulty in verbal expression. He had a history of pseudotumor in the left tibia, which had been treated by surgery 3 years ago. CT and MRI demonstrated bilateral extra-axial lesions with bone destruction (figure 1). ${ }^{1}$ These extremely rare cranial hemophilic pseudotumors were totally resected after adequate replacement therapy (figure 2). ${ }^{2}$ Histologic examination disclosed a coagulum of blood products surrounded by a fibrous capsule with hemosiderin-laden macrophages.

Zhe Zhang, $M D$, Yu Zhu, MD, Ze-Bin Fang, MD, Ying Tong, MD, PhD

From the First Affiliated Hospital, School of Medicine, Zhejiang University, Hangzhou, China.

Author contributions: Dr. Zhang: drafting the manuscript. Dr. Zhu: analysis and interpretation of data. Dr. Fang: analysis and acquisition of data. Dr. Tong: revising the manuscript.

Study funding: No targeted funding reported.

Disclosure: The authors report no disclosures relevant to the manuscript. Go to Neurology.org for full disclosures.

Correspondence to Dr. Tong: tongying216@gmail.com

1. Horton DD, Pollay M, Wilson DA, et al. Cranial hemophilic pseudotumor: case report. J Neurosurg 1993;79:936-938.

2. Sim KB, Hong SK. Cranial hemophilic pseudotumor: case report. Neurosurgery 1996;39:1239-1242. 


\title{
Neurology
}

\author{
Bilateral cranial hemophilic pseudotumors \\ Zhe Zhang, Yu Zhu, Ze-Bin Fang, et al. \\ Neurology 2014;82;638-639 \\ DOI 10.1212/WNL.0000000000000129
}

This information is current as of February 17, 2014

\section{Updated Information \&} Services

References

Subspecialty Collections

Permissions \& Licensing

Reprints including high resolution figures, can be found at: http://n.neurology.org/content/82/7/638.full

This article cites 2 articles, 0 of which you can access for free at: http://n.neurology.org/content/82/7/638.full\#ref-list-1

This article, along with others on similar topics, appears in the following collection(s):

All Imaging

http://n.neurology.org/cgi/collection/all_imaging Hematologic

http://n.neurology.org/cgi/collection/hematologic

Information about reproducing this article in parts (figures,tables) or in its entirety can be found online at:

http://www.neurology.org/about/about_the_journal\#permissions

Information about ordering reprints can be found online:

http://n.neurology.org/subscribers/advertise

Neurology ${ }^{\circledR}$ is the official journal of the American Academy of Neurology. Published continuously since 1951, it is now a weekly with 48 issues per year. Copyright @ 2014 American Academy of Neurology. All rights reserved. Print ISSN: 0028-3878. Online ISSN: 1526-632X.

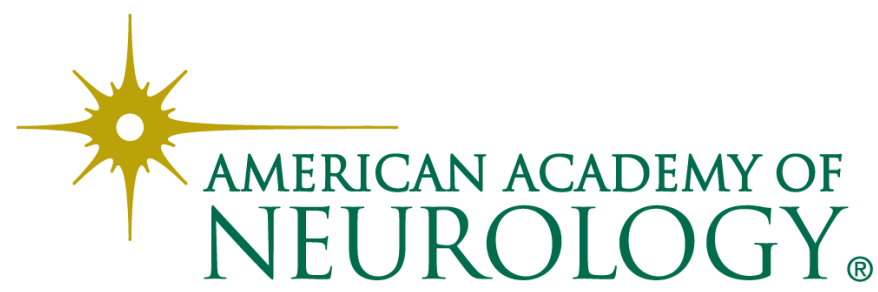

